\title{
ASPEK REPRODUKSI KEPITING BAKAU (Scylla sp.) DI PERAIRAN KENDAL, JAWA TENGAH
}

\section{REPRODUCTION ASPECTS OF MUD CRAB (Scylla sp.) IN KENDAL WATERS, CENTRAL JAVA}

\author{
Ester Tiurlan, Ali Djunaedi dan Endang Supriyantini* \\ Program Studi IImu Kelautan, Fakultas Perikanan dan IImu Kelautan, Universitas Diponegoro \\ Jl. Prof. H. Soedarto, S.H. Tembalang, Semarang Jawa Tengah 50275 Indonesia \\ Email: supri_yantini@yahoo.com
}

\begin{abstract}
ABSTRAK
Kepiting bakau Scylla sp. merupakan salah satu biota laut yang mempunyai nilai ekonomis penting. Penyebarannya hampir di seluruh kawasan pesisir Indonesia, yang memiliki ekosistem mangrove termasuk di perairan Kendal. Banyaknya penangkapan kepiting bakau tanpa memperhatikan ukuran yang layak tangkap. Oleh karena itu penelitian ini dilakukan untuk memperoleh beberapa aspek reproduksi kepiting bakau Scylla sp. di perairan Kendal, Jawa Tengah. Pengambilan sampel dilakukan pada bulan Februari-Maret 2017, dua minggu sekali selama dua bulan di perairan Kendal, Jawa Tengah. Metode yang digunakan dalam penelitian ini adalah metode deskriptif eksploratif dengan parameter pendukung seperti suhu, salinitas, $\mathrm{pH}$, dan DO. Materi yang digunakan adalah kepiting bakau Scylla sp. Analisis yang digunakan untuk menghitung perbandingan jumlah kepiting bakau jantan dan betina adalah uji chi square. Hasil penelitian menunjukkan bahwa komposisi ukuran kepiting bakau mempunyai lebar karapas 81-130 mm, berat 100-350 gram dengan ukuran rata-rata yang tertangkap $99,62 \mathrm{~mm}$, perbandingan jantan dan betinanya 1:2,09. Hubungan lebar karapas dengan berat menunjukkan sifat allometrik positif. Faktor kondisi yang didapatkan adalah 1,0185. Tingkat kematangan gonad kepiting bakau di dominasi oleh TKG II, nilai indeks kematangan gonad pada kepiting bakau betina berkisar antara 6,84\% - 18,49\%. Tingkat kematangan gonad yang di dominasi oleh TKG II dikarenakan di lokasi penelitian tidak sedang masa pemijahan.
\end{abstract}

Kata Kunci : Kepiting Bakau, Scylla sp., Aspek Reproduksi, Perairan Kendal

\section{ABSTRACT}

Mud crab (Scylla sp.) is the one of marine species that it has value economically important. It spreads in almost all over coastal areas of Indonesia, which has the mangrove ecosystem. Mangrove crab has a high nutritional value. Thus, encouraging people in Kendal captured to consume a large amount of Mud crab and reach the local market demand. This led to the occurrence of a lot of Mud crab catching regardless of the size of the catch.Therefore, this study was conducted to obtain some of reproduction aspects of Scylla sp. in the Kendal waters, Central Java. Sampling was conducted in February-March 2017, every two weeks in two months in Kendal waters, Central Java. The method used in this research was descriptive explorative method with supporting parameters such as temperature, salinity, $\mathrm{pH}$, and $\mathrm{DO}$. The used material was Mud crab (Scylla sp.). Chi square test was used to analyze and calculate the ratio of male and female Mud crabs. The results showed that the size composition of Mud crab had a carbide width of $71-130 \mathrm{~mm}$, weight of 100-350 grams, with average size captured was $99.62 \mathrm{~mm}$, male and female ratio of 1: 2.09. The Relations between width and weight of caparace indicated negative allometric properties. The obtained condition factor was 1.0184767. Maturity level of mangrove crab gonad was dominated by TKG II, gonad index maturity value on female Mud crab ranged between $6.84 \%-18.49 \%$. The maturity level of gonad was dominated by TKG II, because the research location was not in the spawning period.

Keywords : Mud crab, Scylla sp., Reproduction Aspect, Kendal Waters 


\section{PENDAHULUAN}

Perairan Kendal, Jawa Tengah
merupakan salah satu daerah pesisir penghasil kepiting bakau yang cukup potensial. Perairan tersebut merupakan daerah ekosistem mangrove. Menurut Knuckey (1999), kepiting bakau Scylla sp. merupakan kepiting portunidae yang menempati habitat mangrove. Penyebarannya hampir di seluruh kawasan pesisir Indonesia, yang memiliki ekosistem mangrove (Serosero, 2011). Masyarakat di daerah Kendal umumnya menangkap kepiting bakau sebagai bahan pangan disamping untuk memenuhi permintaan pasar lokal maupun mancanegara. Permintaan kepiting bakau di pasaran lokal maupun mancanegara dari waktu ke waktu semakin meningkat. Hal ini dibuktikan dari volume ekspor kepiting dan rajungan Indonesia mencapai 29,038 ton dengan nilai ekspor mencapai USS 321,842. Pada bulan Januari-November Tahun 20162017 peningkatan nilai ekspor kepiting dan rajungan sebesar 29,46 \% (BPS, 2018). Dilaporkan pula oleh Dirjen Perikanan Budidaya bahwa nilai ekspor kepiting dan rajungan 2012-2017 tumbuh 6,06 \%. Tingginya permintaan kepiting memicu intensitas penangkapan kepiting di alam semakin tinggi.

Masyarakat nelayan Kendal melakukan kegiatan penangkapan kepiting bakau hingga saat ini tanpa pengaturan yang jelas sesuai dengan kaidah pengelolaan sumberdaya perikanan. Nelayan memiliki kecenderungan kapan dan dimana saja dengan bebas melakukan penangkapan termasuk kepiting bakau yang masih berukuran belum layak tangkap. Hal ini dibuktikan dari ukuran lebar karapas kepiting yang ditemukan selama penelitian rata-rata $99,62 \mathrm{~mm}$ dan jumlahnya yang semakin menurun. Penurunan populasi dan penurunan produksi kepiting bakau diduga disebabkan oleh adanya peningkatan eksploitasi kepiting bakau, degradasi habitat, dan perubahan lingkungan.

Pemantauan serta pendataan tangkapan kepiting bakau oleh masyarakat nelayan Kendal belum terpantau secara optimal. Hal ini sulit dilakukan mengingat hasil tangkapan kepiting bakau yang diperoleh nelayan umumnya dijual langsung ke pengepul atau tengkulak, pengumpul, pembeli, atau bahkan ke pedagang langsung.

Kepiting bakau banyak digemari oleh sebagian besar masyarakat karena kelezatannya dan mempunyai nilai gizi yang tinggi. Menurut Kasry (1996) kandungan protein kepiting bakau $65,72 \%$ dan lemak $0,88 \%$, sedangkan ovarium (telur) kepiting bakau mengandung $88,55 \%$ protein dan $8,16 \%$ lemak.

Berdasarkan peraturan pemerintah No. 1/Permen-KP/2015, menyatakan bahwa penangkapan kepiting hanya boleh dilakukan apabila lebar karapas lebih dari $15 \mathrm{~cm}$ dan berat $300 \mathrm{~g}$ dan dilarang menangkap kepiting bakau dalam kondisi bertelur, apabila kepiting bakau yang tertangkap ukuran 15 $\mathrm{cm}$ dan kondisi bertelur maka wajib dilepaskan.

Berdasarkan hal tersebut maka diperlukan suatu upaya peningkatan pemanfaatan dan pengelolaan kepiting bakau secara optimal dan berkelanjutan, sehingga diperlukan penelitian tentang aspek biologi reproduksi kepiting bakau. Tujuan penelitian ini yaitu untuk mengetahui biologi reproduksi kepiting bakau, meliputi pengukuran lebar karapas, hubungan lebar karapas dan berat, nisbah kelamin, mengetahui faktor kondisi, tingkat kematangan gonad dan indeks kematangan gonad.

\section{METODE PENELITIAN}

Metode yang digunakan dalam penelitian ini adalah metode deskriptif eksploratif, yaitu suatu metode yang menggambarkan informasi secara sistematis, faktual mengenai sifat dari suatu biota serta faktor yang mempengaruhi biota dan hubungannya terhadap suatu ekosistem (Suryabrata, 1998). Sampel Kepiting bakau diambil dari bulan Februari - Maret 2017 dengan frekuensi pengambilan setiap 2 minggu sekali selama dua bulan.

Sampel Kepiting Bakau (Scylla sp.) yang digunakan dalam penelitian berjumlah 136 ekor, didapatkan dari dua pengepul hasil tangkapan nelayan Kepiting Bakau yang terkumpul di kawasan perairan Kendal, Jawa Tengah. Bubu lipat merupakan salah satu alat tangkap yang umum digunakan oleh masyarakat nelayan di Kendal. Pengukuran lebar karapas kepiting bakau mengacu pada Overton et al. (1997), menggunakan jangka sorong dengan ketelitian 0,01 mm. sedangkan berat sampel kepiting bakau ditimbang menggunakan timbangan digital elektronik dengan ketelitian 0,01 $\mathrm{g}$. Pengukuran lebar karapas ini dilakukan, karena kepiting bakau memiliki lebar karapas yang lebih besar jika dibandingkan dengan panjang tubuhnya (Kanna, 2002). Pengamatan ciri kelamin dilakukan dengan mengamati bentuk abdomen kepiting, jika 
mengerucut adalah jantan sedangkan betina melebar (Kasry, 1996). Tingkat kematangan gonad diamati melalui ciri morfologi, mengacu pada modifikasi Poovachiranon (1992), yang membagi tingkat kematangan gonad kepiting bakau menjadi 5 kategori. Parameter fisika-kimia perairan yang diukur sebagai data pendukung meliputi suhu, salinitas, $\mathrm{pH}$, dan $\mathrm{DO}$.

\section{Analisis Hubungan Lebar Karapas dan Berat}

Untuk mengetahui pola pertumbuhan kepiting bakau dapat diketahui dari hubungan antara lebar karapas dan berat total kepiting, dihitung berdasarkan persamaan Effendie (2002) sebagai berikut:

$$
\mathrm{W}=\mathrm{a} \cdot \mathrm{L}^{\mathrm{b}}
$$

Keterangan : $\mathrm{W}=$ Berat kepiting $(\mathrm{g}) ; \mathrm{L}=$ Lebar karapas $(\mathrm{mm}) ; \quad a=$ Intersep (perpotongan kurva hubungan lebar berat dengan sumbu $\mathrm{Y}$ ); $\mathrm{b}=$ Penduga pola pertumbuhan lebar dan berat

Menurut Effendie (2002) korelasi hubungan lebar karapas dengan berat tubuh dapat dilihat dari nilai konstanta $b$, yaitu: Bila $\mathrm{b}=1$, dikatakan hubungan isometrik (pola pertumbuhan lebar karapas sama dengan pola pertumbuhan berat tubuh). Bila $b \neq 1$, dikatakan memiliki hubungan allometrik, yaitu : Bila $b>1$, allometrik positif (pertumbuhan berat tubuh lebih cepat daripada pertumbuhan lebar karapas); bila $b$ $<1$, allometrik negatif (pertumbuhan lebar karapas lebih cepat daripada pertumbuhan berat tubuh)

\section{Faktor Kondisi}

Faktor kondisi menunjukkan keadaan baik buruknya biota dilihat dari segi kapasitas fisik. Perhitungan faktor kondisi terlebih dahulu diketahui pola pertumbuhan biota tersebut yaitu berdasarkan pada lebar karapas dan berat total (Effendie, 2002), sebagai berikut:

$\mathrm{Kn}=\frac{W \cdot 10^{5}}{W^{L}}$ apabila $\mathrm{b}=1$, bersifat isometrik $\mathrm{Kn}=\frac{W^{L}}{a L^{b}}$ apabila $\mathrm{b} \neq 1$, bersifat allometrik

Keterangan : $\mathrm{Kn}=$ Faktor kondisi setiap kepiting; $\mathrm{W}=$ Berat kepiting $(\mathrm{g}) ; \mathrm{L}=$ Lebar karapas kepiting $(\mathrm{mm}) ; \mathrm{a}=$ Intersep (perpotongan kurva hubungan lebar berat dengan sumbu $\mathrm{Y}) ; \mathrm{b}=$ penduga pola pertumbuhan lebar dan berat

\section{Nisbah Kelamin}

Nisbah kelamin atau sex ratio adalah bagian dari jantan dan betina dalam suatu populasi. Nisbah jantan betina ini dapat dihitung menggunakan rumus Effendie (2002), sebagai berikut:

$$
\mathrm{Pj}=\frac{A}{B} x 100 \%
$$

Keterangan: $\mathrm{Pj}=$ Nisbah kelamin jantan atau betina; $\mathrm{A}=$ Jumlah jenis kepiting bakau dengan kelamin tertentu (jantan atau betina); $B=$ Jumlah total individu kepiting bakau yang ada (ekor).

Hubungan antara jantan dan betina dalam suatu populasi dapat diketahui dengan melakukan analisis nisbah kelamin kepiting bakau menggunakan uji Chis-quare ( Steel dan Torrie, 1993), sebagai berikut:

$$
\mathrm{X}^{2}=\sum \frac{(O i-e i)^{2}}{e i}
$$

Keterangan : $\mathrm{X}^{2}=$ Sebuah nilai bagi peubah acak $\mathrm{x}^{2}$ yang sebaran penarikan contohnya mendekat sebaran $x^{2}$; oi $=$ Frekuensi kepiting jantan dan betina yang teramati; ei = Frekuensi harapan, yaitu frekuensi kepiting jantan ditambah betina dibagi dua

\section{Tingkat Kematangan Gonad}

Penentuan Tingkat Kematangan Gonad (TKG) kepiting .jantan dan betina dilakukan dengan klasifikasi berdasarkan deskripsi menggunakan pendekatan Poovachiranon (1992) (Tabel 1.).

Indeks Kematangan Gonad (IKG) dihitung menggunakan rumus menurut Effendie (2002), yaitu :

$$
\mathrm{IKG}=\frac{B g}{B t} \times 100 \%
$$

Keterangan: IKG $=$ Indeks kematangan gonad $(\%) ; \mathrm{Bg}=$ Berat gonad $(\mathrm{g}) ; \mathrm{Bt}=$ Berat tubuh $(\mathrm{g})$.

\section{HASIL DAN PEMBAHASAN}

\section{Ukuran Lebar Karapas Kepiting Bakau Di Lokasi Penelitian}

Hasil tangkapan kepiting bakau (Scylla sp.) di perairan Kendal diperoleh sebanyak 136 ekor terdiri dari 44 ekor kepiting jantan dan 92 ekor kepiting betina. Berdasarkan hasil pengukuran lebar karapas, terbagi 
menjadi lima kelas ukuran untuk kepiting jantan dan betina (Gambar 1).

Hasil pengukuran diperoleh kisaran ukuran lebar karapas kepiting jantan terbanyak pada interval kelas 91-100 mm sebanyak 31 ekor, sedangkan pada kepiting betina memiliki ukuran lebar karapas terbanyak juga pada interval 91-100 mm sebanyak 39 ekor. Kisaran kelompok bobot kepiting bakau jantan yang paling banyak tertangkap yaitu 154,67-194,23 g sebanyak 23 ekor, sedangkan pada kepiting betina memiliki kisaran bobot terbanyak pada kisaran yang sama yaitu 154,67-194,23 g sebanyak 51 ekor (Gambar 2).

Hasil ini berbeda dengan penelitian yang dilakukan Asmara et al. (2011), lebar karapas Scylla serrata jantan paling banyak tertangkap di Perairan Segara Anakan Kabupaten Cilacap JawaTengah pada bulan Oktober yaitu kisaran 86,0-96,8 mm dengan frekuensi sebesar 74,07 \%, sedangkan pada betina terbanyak tertangkap pada kisaran 75,1-85,9 mm dengan frekuensi sebesar 45 \%. Dilaporkan pula oleh Arfiati et al. (2017), di Pesisir Kabupaten Probolinggo didapatkan kisaran lebar karapas Scylla serrata pada bulan April-Mei antara 54,2-127,4 mm dengan berat tubuh berkisar 32,73-352,51 g, dan diperoleh nisbah kelamin kepiting dengan perbandingan 1,15 jantan : 1 betina. Variasi ukuran lebar karapas kepiting bakau ini diduga karena perbedaan waktu dan lokasi pengambilan sampel. Terlihat bahwa pada daerah tertentu ditemukan kepiting bakau dengan ukuran lebar karapas yang lebih kecil, diduga kepiting bakau sedang melakukan proses rekruitmen, sehingga kepiting yang ditangkap merupakan kepiting yang masih muda. Seperti halnya di perairan
Kendal diduga sebagian besar kepiting telah melakukan tahap pemijahan. Menurut Poovachiranon (1992), populasi kepiting betina dewasa meningkat menjelang akhir musim penghujan dan pada awal datangnya musim kemarau, pada saat itu diduga kepiting sedang mengalami migrasi kearah perairan pantai yang memiliki hutan mangrove untuk berlindung, mencari makan dan membesarkan diri, sehingga banyak ditemukan kepiting yang masih muda, dan didapatkan ukuran lebar karapas yang lebih kecil. Faktor lain yang menyebabkan ukuran kepiting yang tertangkap semakin kecil adalah karena tekanan penangkapan yang tinggi terhadap sumberdaya kepiting bakau di perairan. Menurut Sara (2000), pengaruh eksploitasi yang berlebihan ditunjukkan dengan menurunnya ukuran rata-rata kepiting bakau yang tertangkap dan yang didaratkan.

Ukuran kepiting bakau diduga juga berkaitan dengan kondisi hutan mangrove. Berkurangnya luas hutan mangrove berpengaruh terhadap habitat dan ketersediaan makanan bagi kepiting bakau, sehingga kepiting yang tertangkap memiliki ukuran yang lebih kecil. Menurut Sodikin (2012), kerusakan hutan mangrove di Indonesia sudah tergolong cukup parah, yaitu sudah mencapai 68 \% dan kawasan hutan mangrove di Pantai Utara Jawa di perkirakan hanya tinggal $10 \%$. Menurut Dinas Kehutanan Provinsi Jawa Tengah (2013), Iuas hutan mangrove di Jawa Tengah adalah $56,535.75 \mathrm{Ha}$ dan luas hutan mangrove di Kabupaten Kendal sendiri adalah 2,205.47 Ha. Sebagian masyarakat pesisir Kendal memanfaatkan areal ekosistem mangrove untuk digunakan sebagai areal pertambakan,

Tabel 1. Klasifikasi TKG Kepiting Bakau (Scylla sp.)

\begin{tabular}{|c|c|c|}
\hline TKG & Jantan & Betina \\
\hline I & $\begin{array}{l}\text { Testis seperti filament, berwarna } \\
\text { putih jernih, terletak dekat } \\
\text { jantung di bawah hati }\end{array}$ & $\begin{array}{l}\text { Ovarium belum berkembang \& berbentuk sepasang } \\
\text { filament yang mengarah ke bawah punggung } \\
\text { terletak di atas kelenjar pencernaan yang berwarna } \\
\text { kuning, ovarium berwarna jernih keputihan. }\end{array}$ \\
\hline II & $\begin{array}{l}\text { Testis mulai membesar berwarna } \\
\text { putih jernih kesekitarnya }\end{array}$ & $\begin{array}{l}\text { Ukuran ovarium bertambah \& mulai meluas, warna } \\
\text { putih susu }\end{array}$ \\
\hline III & $\begin{array}{l}\text { Testis bentuknya jelas berwarna } \\
\text { putih susu }\end{array}$ & $\begin{array}{l}\text { Ovarium bertambah hingga kesekitarnya, warna } \\
\text { menjadi kuning pucat. }\end{array}$ \\
\hline IV & $\begin{array}{l}\text { Seperti TKG III, namun } \\
\text { ukurannya semakin besar }\end{array}$ & $\begin{array}{l}\text { Volume ovarium semakin membesar, hampir mengisi } \\
\text { seluruh rongga dada. Telur berwarna kuning pucat } \\
\text { sampai kuning emas, kelenjar pencernaan makin } \\
\text { mengecil terdesak oleh ovarium, butiran telur dapat } \\
\text { terlihat dengan bantuan mikroskop }\end{array}$ \\
\hline V & $\begin{array}{l}\text { Testis terlihat jelas warna putih } \\
\text { susu \& bentuk semakin pejal. }\end{array}$ & $\begin{array}{l}\text { Ovarium penuh dengan sel, hampir matang } \\
\text { berwarna oranye sampai merah tua,jika karapas } \\
\text { dibuka hamper seluruh dada hanya birisi ovarium }\end{array}$ \\
\hline
\end{tabular}




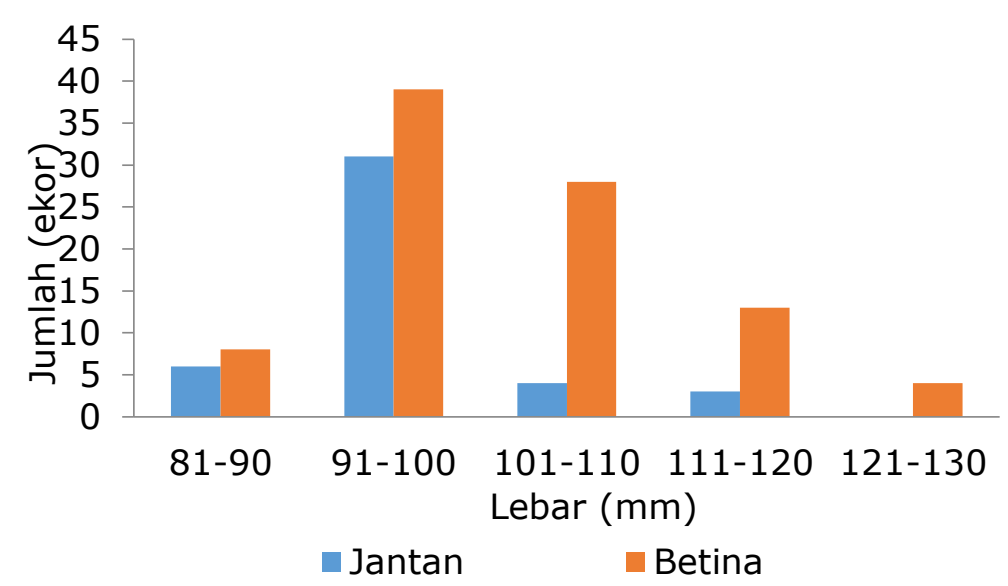

Gambar 1. Lebar Karapas Kepiting Bakau (Scylla sp.) Jantan dan Betina Hasil Tangkapan di Perairan Kendal

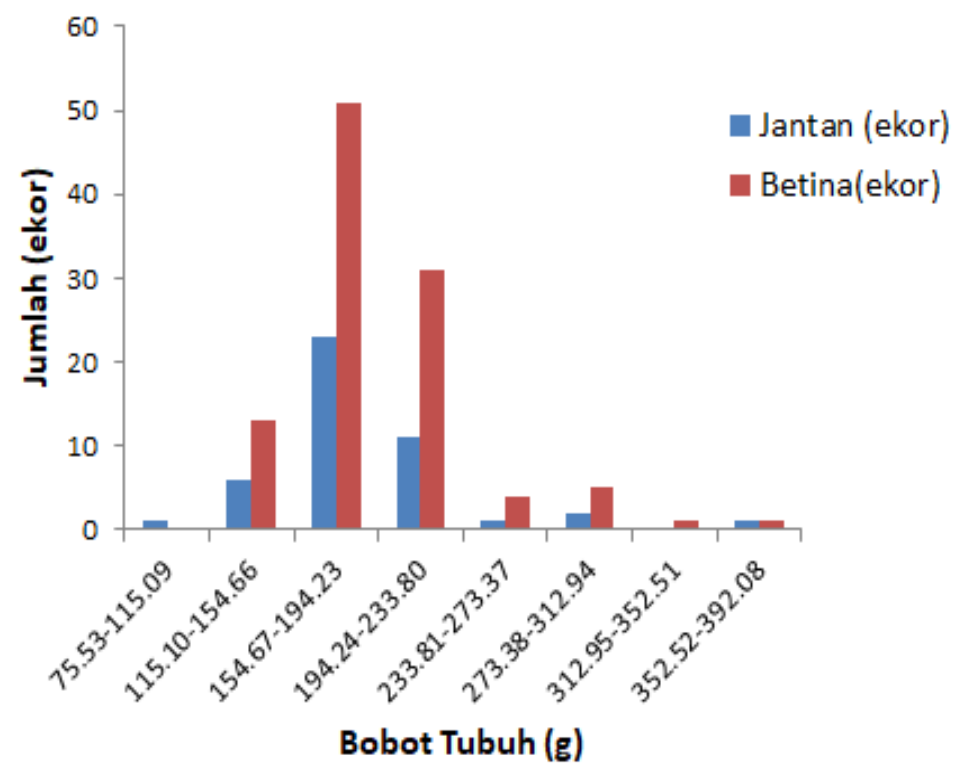

Gambar 2. Kisaran Bobot Kepiting Bakau (Scylla sp.) Jantan dan Betina yang Tertangkap di Perairan Kendal.

pemukiman, penebangan liar, dan pembangunan kawasan industri. Hal ini akan memberi tekanan pada hutan mangrove di daerah tersebut sehingga kawasan mangrove mengalami kerusakan dan penyempitan lahan. Kondisi ini akan berpengaruh terhadap pertumbuhan kepiting bakau yang ada di perairan tersebut.

\section{Hubungan antara Lebar Karapas dengan Berat Tubuh Kepiting Bakau}

Hubungan lebar karapas dengan berat tubuh kepiting bakau mempunyai persamaan $W=0,345 \quad L^{1,371} \quad$ (Gambar 3). Pola pertumbuhan kepiting bakau bersifat allometrik positif karena nilai b yang diperoleh adalah sebesar 1,371. Artinya pertumbuhan berat tubuh kepiting lebih cepat dibandingkan pertumbuhan lebar karapas. Nilai koefisien korelasi yang didapatkan pada penelitian ini menunjukkan adanya korelasi positif yang kuat antara berat tubuh dengan lebar karapas $(r=0,627)$ (Hasan, 2002). Ini berarti bahwa perubahan berat tubuh mempunyai pengaruh terhadap lebar karapas, yakni semakin berat tubuh maka semakin lebar karapas kepiting bakau.

Tingginya nilai parameter pertumbuhan (b) pada penelitian ini diduga disebabkan adanya ketersediaan makanan yang baik dari segi kuantitas dan kualitas dalam menunjang pertumbuhan kepiting bakau, kondisi habitat dan faktor lingkungan yang sesuai. Faktor lain yang menyebabkan tingginya nilai parameter pertumbuhan adalah akibat adanya eksploitasi yang berlebih di alam sehingga kepiting tidak memiliki kesempatan untuk melakukan rekruitmen terhadap stok yang baru sehingga banyak ditemukan kepiting muda berukuran lebih kecil namun lebih cepat mengalami kematangan gonad. 


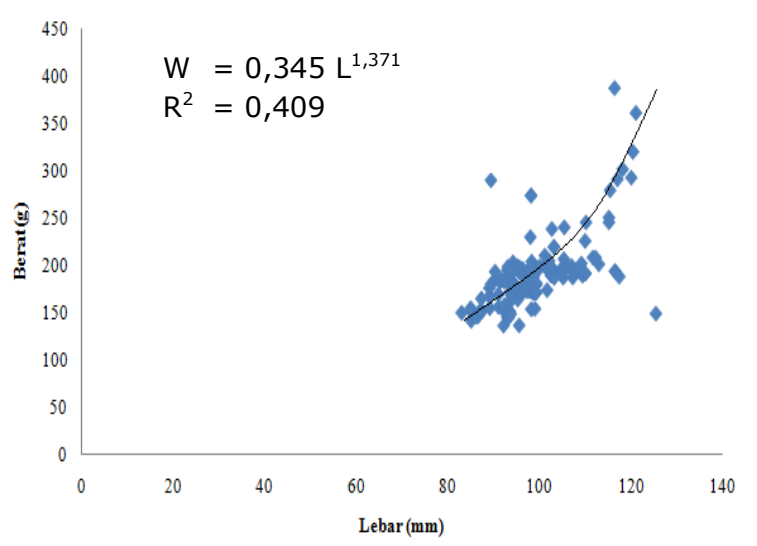

Gambar 3. Hubungan Lebar Karapas dengan Berat Kepiting Bakau (Scylla sp.)

Kondisi seperti ini secara tidak langsung akan berpengaruh terhadap berat tubuh kepiting bakau.

Hasil pengukuran parameter lingkungan di lokasi penelitian meliputi suhu 30,532,5० ; salinitas 31,3-36,8 ppt; dan $\mathrm{pH} 6,9-$ 7,1. Menurut Shelley and Lovatelli (2011), suhu merupakan faktor yang paling berpengaruh terhadap pertumbuhan kepiting bakau, suhu yang optimal untuk pertumbuhan kepiting lebih cepat yakni pada kisaran 25-35० $\mathrm{C}$; pH 6,5-7,5 (Siahainenia, 2008); salinitas optimal 15-25 ppt dan pertumbuhan lebih lambat jika berada pada salinitas $>25-30$ ppt (Setiawan dan Triyanto, 2012). Namun menurut Sara et al. (2006), Scylla serrata dapat mentolerir kisaran salinitas yang besar yaitu 2-40 ppt.

Hasil pengukuran salinitas dan suhu di lapangan akan berpengaruh terhadap pertumbuhan kepiting bakau $S$. serrata. Perubahan salinitas akan berpengaruh terhadap sifat fungsional dan struktur organisme, sedangkan perubahan suhu sangat berperan dalam kecepatan metabolisme dan kegiatan organisme lainnya (Kasry, 1996). Salinitas juga mempengaruhi proses pematangan gonad. Perubahan TKG kepiting bakau berkaitan dengan tingginya salinitas. Gunarto et al. (2001), melaporkan bahwa perkembangan kematangan gonad paling baik adalah pada salinitas 25-28 ppt.

\section{Faktor Kondisi}

Hasil perhitungan analisis data diperoleh faktor kondisi (Kn) kepiting bakau sebesar 1,0185, ini artinya kepiting bakau mempunyai tubuh yang pipih (tidak gemuk). Menurut Effendie (2002), tubuh kepiting dikatakan gemuk jika mempunyai nilai $\mathrm{Kn}$ berkisar 3-4, sedangkan tubuh kepiting pipih jika nilai $\mathrm{Kn}$ berkisar 1-2. Nilai faktor kondisi sangat dipengaruhi oleh faktor eksternal, yaitu lingkungan dan faktor internal, yaitu tingkat perkembangan gonad, laju pertumbuhan, nafsu makan dan jumlah parasit pada tubuh kepiting. Musim dan jumlah populasi juga dapat mempengaruhi nilai faktor kondisi pada kepiting bakau (Khan, 2014). Nilai faktor kondisi dapat naik dan dapat turun. Kenaikan faktor kondisi $(\mathrm{Kn})$ mengindikasikan kepiting mengalami pertumbuhan, pengisian gonad dengan sel telur. Sedangkan penurunan nilai $\mathrm{Kn}$ merupakan indikasi dari musim pemijahan khususnya kepiting bakau betina, selain itu juga faktor makanan. Faktor kondisi (indeks ponderal) merupakan indeks yang dapat digunakan untuk menunjukkan kondisi atau keadaan organisme ditinjau dari segi kapasitas fisik untuk bertahan hidup dan reproduksi (Effendie, 2002).

\section{Nisbah Kelamin}

Nisbah kelamin merupakan perbandingan jumlah kepiting jantan dan betina dalam suatu populasi. Penentuan nisbah kelamin dilakukan dengan melihat morfologi kepiting yaitu dengan melihat bentuk/morfologi abdomen. Perbandingan yang didapat antara kepiting jantan dan betina diperairan Kendal adalah 1:2,09. Hal ini berarti nisbah kelamin kepiting jantan dan betina tidak seimbang atau dengan kata lain jumlah kepiting jantan lebih sedikit daripada jumlah kepiting betina. Berdasarkan perhitungan uji chi-square pada selang kepercayaan $95 \%$ didapatkan $x^{2}$ hitung $(16,941)>x^{2}$ tabel $(3,375)$. Perbedaan nilai nisbah kepiting betina lebih tinggi dibandingkan kepiting jantan, hal ini diduga berkaitan dengan ketersediaan makanan dan siklus hidup kepiting bakau terutama pada masa reproduksi. Sesuai pendapat Hill (1982) komposisi nisbah kelamin akan mengikuti perubahan musim pemijahannya. Hal tersebut menunjukkan bahwa pada bulan pengambilan sampel kepiting yaitu bulan Februari-Maret mulai terjadi musim migrasi kepiting setelah memijah, sehingga dapat diperkirakan bahwa musim pemijahan kepiting bakau $S$. serrata terjadi pada bulan sebelum Februari-Maret.

\section{Tingkat Kematangan Gonad (TKG)}

Penentuan tingkat kematangan gonad kepiting bakau didasarkan pada perkembangan gonad secara morfologi, yaitu ditentukan berdasarkan warna, ukuran dan pemenuhan gonad dalam rongga tubuh 
kepiting bakau (Scylla sp.). TKG kepiting bakau yang didapatkan selama penelitian sebagian besar memiliki TKG II yang lebih banyak daripada TKG lainnya dengan ciri-ciri sesuai dengan yang dilakukan oleh Poovachiranon (1992), yaitu ovarium meluas kesekitarnya dan berwarna putih susu (Gambar 4). Jumlah kepiting TKG II yang lebih banyak dikarenakan pada saat pengambilan sampel, belum mencapai puncak pemijahan kepiting.

Menurut Kasry (1996), pada bulan Februari sampai dengan bulan Maret, dimana pada bulan tersebut terjadi pergantian musim hujan menuju musim kemarau, pada kondisi tersebut suhu perairan maupun salinitas lingkungan akan berpengaruh terhadap tingkah laku pemijahan kepiting bakau yang berada di suatu perairan. Hasil pengukuran suhu dan salinitas dilapangan adalah $30,5-32,5^{\circ} \mathrm{C}$ dan $31,3-36,8$ ppt.

\section{Indeks Kematangan Gonad (IKG)}

Indeks Kematangan Gonad kepiting bakau menunjukkan perbandingan antara berat gonad dengan berat tubuh. IKG kepiting bakau betina hasil penelitian berkisar $6,84-18,49 \%$. Variasi nilai IKG dipengaruhi oleh faktor lingkungan, genetik, kepadatan, dan faktor seleksi akibat tekanan predator (Widhiastuti, 2008). Menurut Effendie (2002) indeks kematangan gonad akan semakin meningkat nilainya apabila mencapai batas maksimal saat kepiting akan memijah. Menurut Poovachiranon (1992), secara fisiologis kepiting matang pada ukuran lebar karapas antara 85-138 mm. Hal ini berbeda dengan kepiting bakau hasil penelitian, pada hasil penelitian banyak ditemukan ukuran lebar karapas kepiting jantan maupun betina berkisar 91-100 mm. Menurut Sianturi et al.

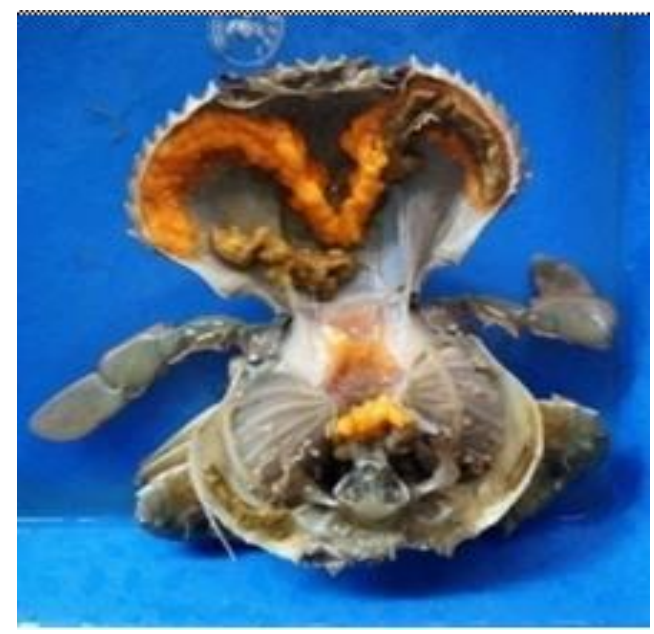

Gambar 4. Tingkat Kematangan Gonad II Kepiting Bakau (Scylla sp.) Betina
(2016), kepiting bakau dikatakan telah dewasa kelamin jika memiliki ukuran lebar karapas lebih dari $100 \mathrm{~mm}$.

\section{KESIMPULAN}

Berdasarkan hasil penelitian kepiting bakau di perairan Kendal Jawa Tengah dapat disimpulkan bahwa pola pertumbuhan kepiting bakau betina maupun jantan bersifat allometrik positif. Tingkat kematangan gonad kepiting bakau didominasi oleh TKG II dan pada bulan pengambilan sampel FebruariMaret sudah melewati masa pemijahan sehingga yang tertangkap kepiting yang masih muda dan berukuran kecil dengan lebar karapas berkisar 91-100 mm.

\section{REFERENSI}

Arfiati, D., J. Michael, P.S., dan Herawati, E.Y. 2017. Aspek Biologi Kepiting Bakau (Scylla serrata) dari Pengepul Desa Curahsawo, Kecamatan Gending, Probolinggo, Jawa Timur. Prosiding Seminar Nasional Kelautan dan Perikanan III. Universitas Trunojoyo Madura. 7 September 2017. Hal 20-27.

Asmara, H., Etty, R., dan Agus, S. 2011. Analisis Beberapa Aspek Reproduksi Kepiting Bakau (Scylla Serrata) Di Perairan Segara Anakan, Kabupaten Cilacap, Jawa Tengah. Jurnal Matematika, Sains dan Teknologi. 12(1): 31-36.

Badan Pusat Statistik. 2018. Kelautan dan Perikanan dalam Angka Tahun 2016-17. Pusat Data, Statistik dan Informasi, Kementerian Kelautan dan Perikanan, Jakarta.

Dinas Kehutanan Provinsi Jawa Tengah. 2013. Luas Kawasan Mangrove Per Kabupaten Di Provinsi Jawa Tengah Tahun 2013155 hlm.

Effendie. 2002. Biologi Perikanan. Yayasan Pustaka Nusantara. Bogor. $155 \mathrm{hlm}$.

Gunarto. U., Pirzan, M., dan Daud, R. 2001. Pematangan Gonad Kepiting Bakau, Scylla spp. Di Perairan Mangrove Muara Sungai Cenranae, Kabupaten Bone, Sulawesi Selatan. Jurnal Penelitian Perikanan Indonesia, 7(1): 47-52.

Hasan, I. 2002. Pokok-Pokok Materi Statistik 1 (Statistik Deskriptif). Bumi Aksara. Jakarta.

Hill, B.J. 1982. The Queensland Mud Crab Fishery. Queensland Fish Inf. Australia. $7 \mathrm{hlm}$.

Kanna, I. 2002. Budidaya Kepiting Bakau: Pembenihan dan Pembesaran. Kanisius.Yogyakarta. $80 \mathrm{hlm}$. 
Kasry, A. 1996. Budidaya Kepiting Bakau dan Biologi Ringkas. Bhatara, Jakarta. 76 hlm.

Khan, M.A. 2014. Some Biological Aspects of The Portunid Crab Scylla serrata (Forsskål, 1775) from Coastal Waters of Karachi, Pakistan. International Journal of Biology and Biotechnology. 11(23): $177-190$.

Knuckey, I. A. 1999. Mud Crab (Scylla serrata) Population Dynamics in the Northern Territory, Australia and Their Relationship to the Commercial Fishery. Thesis. Northern Territory University, Australia. $382 \mathrm{pp}$.

Overton, J.L., Macintosh, D.J., and Thorpe, R.S. 1997. Multivariate Analysis of The Mud Crab Scylla serrata (Brachiura: Portunidae) from Four Locations in South East Asia. Marine Biology, 128(1):55-62.

Peraturan Menteri Kelautan dan Perikanan. 2015. Penangkapan Lobster Panulirus spp., Kepiting Bakau Scylla spp., dan Rajungan Portunus pelagicus spp. Jakarta (ID): PERMEN - KP. $8 \mathrm{hlm}$.

Poovachiranon, S. 1992. Biological Studies of the Mud Crab Scylla serrata (Forskal) of the Mangrove Ecosystem in the Andaman Sea. Report of the Seminar on the Mud Crab Culture and Trade. Tokyo University of Agriculture. Japan. 49-57 hlm.

Sara, L., 2000. Habitat and some biological parameters of two species of mud crab Scylla in Southeast Sulawesi, Indonesia. In JSPS-DGHE International 22 Symposium. Sustainable Fisheries in Asia in the New Millenium. pp. 341-346.

Sara, L., Ingles, J.A., Aguilar, R.O., Laureta, L.V., Baldevarona, R.B. and Watanabe, S., 2006. Abundance and Distribution Patterns of Scylla spp. Larvae in the Lawele Bay, Southeast Sulawesi, Indonesia. Asian Fisheries Sciences, 19:331-347.
Serosero, R. 2011. Karakteristik Habitat Kepiting Bakau (Scylla spp) di Perairan Pantai Desa Todowongi Kecamatan Jailolo Selatan Kabupaten Halmahera Barat. Jurnal IImiah Agribisnis dan Perikanan. 4(1):69-73.

Setiawan, F. dan Triyanto. 2012. Studi Kesesuaian Lahan untuk Pengembangan Silvofishery Kepiting Bakau di Kabupaten Berau, Kalimantan Timur. Limnotek, 19(2):158-165.

Shelley, C. and A. Lovatelli. 2011. Mud Crab Aquaculture a Practical Manual. FAO Fisheries and Aquaculture Technical Paper. 78p

Siahainenia, L. 2008. Bioekologi Kepiting Bakau (Scylla spp.) di Ekosistem Mangrove Kabupaten Subang Jawa Barat.[Disertasi].Sekolah Pascasarjana IPB. Bogor. $246 \mathrm{hlm}$.

Sianturi, A., Basyuni, M. dan Apandy, Z., 2016. Tingkat Kematangan Gonad Kepiting Bakau (Scylla serrata) di Kawasan Hutan Mangrove Sicanang Kecamatan Medan Belawan Sumatera Utara. Aquacoastmarine, 12(2):38-47.

Sodikin. 2012. Persepsi Masyarakat Petani Tambak terhadap Kelestarian Hutan Mangrove Di Desa Pabean Ilir Kecamatan Pasekan Kabupaten Indramayu. Jurnal Gea. 12(1): 40-48.

Steel, R.G.D. dan Torrie, J.H. 1993. Prinsip dan Prosedur Statistika, suatu Pendekatan Biometrik. Edisi kedua. Diterjemahkan oleh Bambang Sumantri. PT Gramedia Pustaka Utama. Jakarta. $748 \mathrm{hlm}$.

Suryabrata. 1998. Metodologi Penelitian. CV. Rajawali Press, Jakarta.

Widhiastuti, R. 2008. Kepadatan dan Distribusi Kepiting Bakau (Scylla spp.) serta Hubungannya dengan Faktor Fisik Kimia di Perairan Pantai Labu Kabupaten Deli Serdang (Tesis), USU. Medan. $57 \mathrm{hlm}$. 